SŁawomir Dorocki, PaweŁ Brzegowy

Uniwersytet Pedagogiczny, Kraków, Polska

\title{
Wpływ polityki innowacyjnej na rozwój przemysłu zaawansowanej technologii $w$ departamentach Francji zamorskiej
}

\author{
Innovation Policy Impact on Technologically Advanced \\ Industries in Overseas France Departments
}

\begin{abstract}
Streszczenie: Intencją niniejszej pracy pozostaje prezentacja atrakcyjności innowacyjnej departamentów i regionów Francji pozaeuropejskiej: Gwadelupy, Martyniki, francuskiej Gujany i Réunion. W oparciu o Stratégie Régionale d'Innovation (SRI) - Regionalne Strategie Innowacji oraz m.in. inicjatywę Synergîle, ukazany zostanie kierunek realizowanych inwestycji, efektywność w kształtowaniu synergii naukowo-biznesowej oraz perspektywy dalszej jej intensyfikacji w warunkach ekonomicznej recesji. Analizie i ocenie poddano takie czynniki, jak akceleracja tworzenia wiedzy, dostępność do podstawowych technik komunikacyjnych, czy systemy elastycznej specjalizacji - uznawane za najważniejsze czynniki przestrzennego kształtowania się gospodarki opartej na wiedzy. Proces jej budowy w departamentach i regionach Francji zamorskiej (DROM) jest konsekwencją urzeczywistniania wytycznych zawartych w Strategii Lizbońskiej oraz w programie Europa 2020. Przykład Francji pozaeuropejskiej dowodzi, iż lokalizacja przemysłów wysokiej techniki odbywać się może nie tylko na poziomie aglomeracji, ale również w obszarach peryferyjnych, tradycyjnie postrzeganych jako mniej atrakcyjne.
\end{abstract}

Abstract: The goal of the study is to present the innovative attractiveness of the extra-European depart-
ments and regions of France (DROM): Guadeloupe, Martinique, French Guiana and Réunion. On the
basis of the Regional Innovation Strategies - Stratégie Régionale d'Innovation (SRI) - and initiatives
of Synergîle, Capenergies and others, the direction of the implemented investments will be presented,
as well as effective creation of research-business synergy and prospects of its further intensification
during economic recession. Such factors as acceleration of knowledge creation, accessibility of basic
communication techniques or systems of flexible specialization - which are the primary determiners of
a knowledge-based economy spatial formation - are subject to analysis and assessment. The process of
its formation in the DROM regions results from the materialization of the Lisbon Strategy and Europe
2020 programme guidelines. The example of the Overseas France proves that technologically advanced
industries may not only be localized in metropolitan areas, but also in peripheral regions, traditionally
viewed as less attractive ones. Moreover, the DROM regions remain to be an exemplification of the 
'learning region' concept, which is proved by the effective involvement of particular innovation centres in the promotion of modern branches of industry.

Slowa kluczowe: DROM, SRI, przemysł zaawansowanej technologii, gospodarka oparta na wiedzy

Key words: DROM, SRI, technologically advanced industry, knowledge-based economy

\section{CEL PRACY}

Celem niniejszego opracowania pozostaje prezentacja realizacji polityki innowacyjnej w departamentach i regionach Francji pozaeuropejskiej (départements et régions d'outre-mer, DROM): Gwadelupy, Martyniki, francuskiej Gujany oraz Réunion. Powszechnie przyjmuje się, że rozwój przemysłu wysokiej techniki inicjuje przekształcenia strukturalne w całej gospodarce regionu, indukuje transfer usług technologicznych oraz prowadzi do wzrostu sektorów gospodarki z nim powiązanych, zaś poziom innowacyjności kraju, wraz z rozwojem kapitału ludzkiego, pozostaje jedną z kluczowych determinant określających stopień jego progresu. Praca na wybranych przykładach ukazuje kierunek realizowanych inwestycji na obszarze DROM, efektywność kształtowania synergii naukowo-biznesowej oraz perspektywy dalszej jej intensyfikacji w warunkach ekonomicznej recesji. Poprzez charakterystykę najważniejszych aktorów z zakresu zamorskich innowacji badawczych, zamiarem autorów jest wykazanie na przykładzie Francji niemetropolitalnej, iż lokalizacja przemysłów wysokiej techniki odbywać się może nie tylko na poziomie rozwiniętych aglomeracji, ale także w obszarach peryferyjnych - tradycyjnie postrzeganych jako mniej atrakcyjne. Pozostają ponadto DROM egzemplifikacją koncepcji regionu „uczącego się” (Świdurska 2009; Godowska 2012), czego dowodem jest efektywne zaangażowanie poszczególnych ośrodków innowacyjnych w promowanie gałęzi industrie leader - przemysłu wiodącego.

\section{WPROWADZENIE}

W ostatnich latach Francja wykazuje wyraźne ambicje nakierowane na zajęcie miejsca światowego lidera z zakresu polityki innowacyjnej - przyjmującej za cel pośrednie lub bezpośrednie wsparcie innowacji i konkurencyjności gospodarki (Dorocki 2008; Ciok, Dobrowolska-Kaniewska 2009) oraz społeczeństwa informacyjnego. Z. Zioło podkreśla, iż przynależy ono do zasadniczych czynników umożliwiających osiągnięcie przewagi konkurencyjnej i wykreowania gospodarki opartej na wiedzy (2009). Pomimo wysokiej jakości francuskich badań naukowych i pułapu wykształcenia elit, wspomnianej pozycji jeszcze jednak nie osiągnęła. Nakłady na innowacyjność, w szczególności w szkolnictwo wyższe, zaliczane są do najpewniejszych lokat warunkujących wzrost metropolitalnego PKB, towarzyszy im jednak znaczne zróżnicowanie regionalne (Dorocki, Jenner 2009). Według Globalnego Indeksu Innowacji za rok 2012, na 141 uczestników Republika zajmowała 24 miejsce (The Global Innovation Index 2012), zaś w raporcie Komisji Europejskiej zaliczono ją do grona 
tzw. innovation followers - zaawansowanych naśladowców (Innovation Union Scoreboard 2011), osiągających wyniki zbliżone do średniej europejskiej'. Wsparcie dla przedsięwzięć innowacyjnych zapewniają Narodowa Agencja ds. Badań (Agence National de la Recherche, ANR), Fundusz konkurencyjności przedsiębiorstw (Fonds de compétitivité des enterprises, FCE) oraz Agencja ds. Innowacji Przemysłowych (Agence de l'innovation Industrielle, AII). Zadaniem ANR jest generowanie nowej wiedzy oraz promowanie partnerstwa pomiędzy placówkami badawczymi a przedsiębiorstwami. Pośrednicząca w ogłaszaniu przetargów na projekty średniookresowe AII wspomagała m.in. rozwój rolnictwa czy produkcję samochodów z napędem hybrydowym (Dorocki 2008).

Pośród najważniejszych hamulców francuskiej gospodarki innowacyjnej zważyć należy na strukturę społeczną, gdzie wskutek procesów globalizacyjnych wyraźnie zwiększają się dysproporcje między zamożnymi a biednymi obszarami oraz na skomplikowaną platformę wspierania innowacji, zróżnicowaną na poziomie departamentalnym, regionalnym i ogólnokrajowym. Istotną determinantę zapóźnienia innowacyjnego DROM stanowi również system edukacji. Nieomal połowa ludności Francji pozaeuropejskiej, licząca 15 lat i więcej, nie dysponuje żadnym wykształceniem lub uzyskała jedynie wykształcenie podstawowe (Dorocki, Brzegowy 2012). Często wzmiankowanym problemem części kontynentalnej pozostaje niezadowolenie z wysokości wynagrodzenia kadry naukowej. Średnia roczna gratyfikacja początkującego naukowca $\mathrm{z}$ tytułem doktora w placówce publicznej wynosiła w $2011 \mathrm{r}$. 24 tys. euro, podczas gdy profesora 48 tys. euro (Francuski system zarządzania innowacjami). Regionalna komparatystyka poziomu edukacji Francji kontynentalnej i zamorskiej wskazuje, iż najwyższymi wynikami kształcenia odznaczały się regiony metropolitalne Rodan Alpy, Bretania, Midi-Pyrénées, Kraj Loary i Île-de-France, najniższe zaś charakteryzowały DROM i Korsykę (Dorocki, Brzegowy 2012).

\section{Polityka INNOWACYJNA FRANCJI}

Jedną z ważniejszych inicjatyw z zakresu intensyfikacji procesów innowacyjnych, zapoczątkowaną w 2002 r., pozostają bieguny konkurencyjności (pôles de compétitivité). Priorytetowym ich zadaniem jest intensyfikacja i zwiększenie wydajności francuskiego przemysłu ${ }^{2}$. Klastering francuski rozwijany jest według modelu polityki centralnie planowanej i finansowany w pierwszej kolejności ze źródeł rządowych i regionalnych. Stosowany wzorzec kooperacji podmiotów gospodarczych, tzw. lokalnych systemów produkcyjnych (systemes productifs locaux, SPL), wymaga operatywnego współdziałania wyspecjalizowanej

1 W zestawieniu UE-27 wyróżniono cztery grupy państw: liderów (Dania, Finlandia, Niemcy, Szwecja), zaawansowanych naśladowców (Austria, Belgia, Cypr, Estonia, Holandia, Irlandia, Luksemburg, Słowenia, Wielka Brytania), umiarkowanych innowatorów (Czechy, Grecja, Hiszpania, Malta, Polska, Portugalia, Słowacja, Węgry, Włochy) oraz nadrabiających zaległości (Bułgaria, Litwa, Łotwa, Rumunia).

2 Obszerną klasyfikację francuskich biegunów konkurencyjności podają M-F. Barthet, M. Thoin, Les pôles de compétitivité, La Documentation française, Paris 2009 oraz J.S. Scandella, Les pôles: réseaux d'excellence et d'innovation. Enquête sur les pôles de compétitivité, Autrement, Paris 2008. 
kadry i infrastruktury materialnej. Przez stanowiący niższą formę technopolii klaster rozumie się koncentrację przedsiębiorstw działających w powiązanych branżach i korzystających ze wspólnych rozwiązań infrastrukturalno-technologicznych (Porter 1998). Pozostają zatem klastry „,ideą przestrzennej współpracy między firmami” (Zioło 2008). Partycypujące w trzeciej fazie rewolucji przemysłowej parki technologiczne, zwane w części metropolitalnej technopoliami, wymagają nie tylko m.in. komputeryzacji i automatyzacji procesów pracy, ale również powiązań operacyjnych z uniwersytetem lub instytutem technologicznym. Dodatkowo pod pojęciem technopolia, jak podkreśla T. Markowski (1999), należy rozumieć udaną synergię aktorów lokalnych i badaczy odpowiadających na zapotrzebowanie przedsiębiorstw.

W zorganizowanym po raz pierwszy w 2004 r. naborze wniosków w zakresie ustanawiania biegunów konkurencyjności, wybrano 67 projektów. W 2009 r. Francja kontynentalna posiadała 71 klastrów (ryc. 1), zatrudniających ok. 9 tys. naukowców (Claeys, Gorges, Habib, Lasbordes, Tron 2009). Zlokalizowane w odległości trzydziestu kilometrów od Paryża Val d'Oise należy do najbardziej znanych i prężnie rozwijających się centrów tego typu z pierwszym miejscem pod względem robotyki przemysłowej. Utworzenie 100 tys. nowych miejsc pracy w okresie ostatnich dwudziestu lat uczyniło z ośrodka pioniera z zakresu dynamiki zatrudnienia w wymiarze ogólnofrancuskim. Prowadzona działalność obejmuje m.in. obszary zdrowia i biotechnologii, przemysłu gumowego i polimerów, oprogramowania i systemów złożonych oraz technologii ekologicznych. Oprócz klastrów innowacyjnych wyposażono Val d'Oise w biznes parki, z których trzy posiadały w 2011 r. status technopolii. Planując budowę nowego zagłębia francuskiego klasteringu w pierwszej kolejności stworzono odpowiednie zaplecze infrastrukturalne: drogowe, kolejowe i lotnicze - nadając bezpośrednie połączenie z międzynarodowym portem lotniczym Ch. de Gaulle’a (Wierzyński 2011). Geograficzne usytuowanie w bezpośrednim sąsiedztwie stolicy ${ }^{3}$ będącej monocentrycznym regionem metropolitalnym i w dominującym pod względem działalności profesjonalnej i ICT regionie Île-de-France, zwiększyło zainteresowanie inwestorów.

Ogólnie należy podkreślić, że działania związane z rozwojem klastrów konkurencyjności skupiają się na kontynencie, podczas gdy efekty w regionach zamorskich są bardzo małe (ryc. 2).

Należy odnotować, iż przez wzgląd na politykę finansowania, wspomniany region jest jednym z najbardziej uprzywilejowanych w całej Francji. Cechuje go najwyższy odsetek osób pracujących w przemyśle wysokich i średnich technologii w ogólnej liczbie pracujących (ponad 10\%) oraz największy udział personelu sektora B+R (Borowiec, Dorocki, Jenner 2009). Równie wysokie wartości pozostają charakterystyczne dla innych regionów metropolitalnych: Północnej Normandii, Alzacji i Franche-Comté (Borowiec, Dorocki 2011). Wartość zrealizowanych projektów rozwojowo-badawczych w przeciągu sześciu ostatnich lat tylko w ramach klastra Mov'eo agregującego m.in. koncerny Bosch, PSA Peugeot, Renault, Sagem oraz Pétrole\&Synthése, przekroczyła wartość 660 mln euro. Uruchomiony w 2006 r.

${ }^{3}$ Paryż z regionem Île-de-France - pozostającym jednocześnie jednym z europejskich regionów rdzeniowych, urzeczywistniają koncepcję wyspy innowacji z wysoką koncentracją wyspecjalizowanych przedsiębiorstw i laboratoriów badawczych (Hingel 1995). 


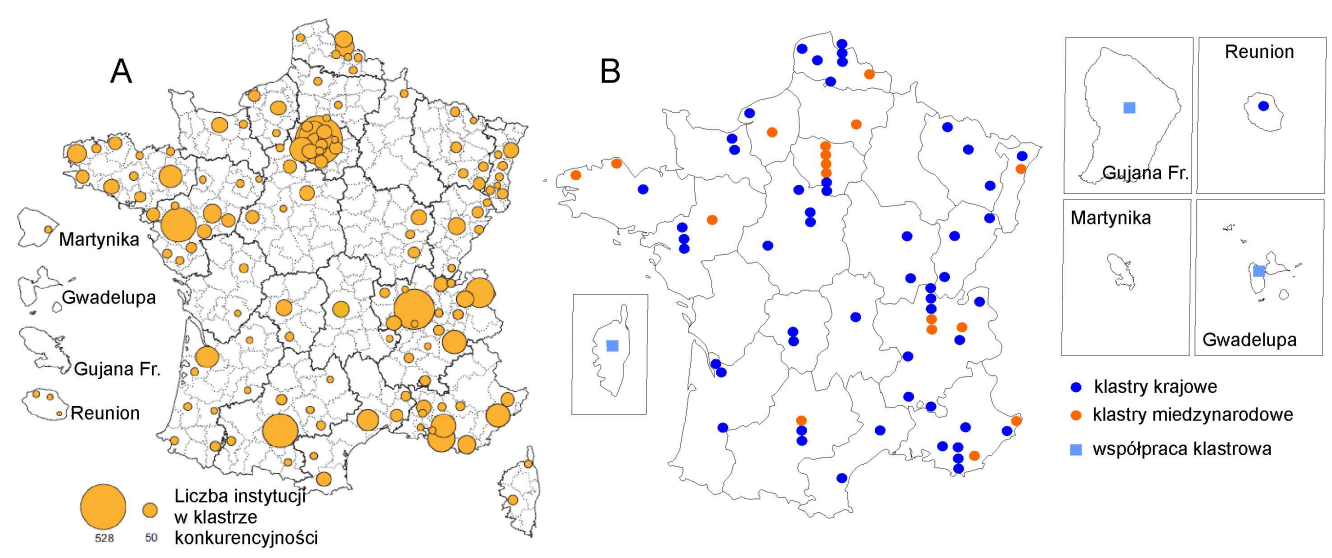

Ryc. 1. Liczba instytucji w klastrach konkurencyjności w 2008 r. (A) oraz typy klastrów (B)

Źródło: En 2008, les pôles de compétitivité ont poursuivi leur expansion, Le 4 Pages, DGCIS N ${ }^{\circ} 7$ - décembre 2009
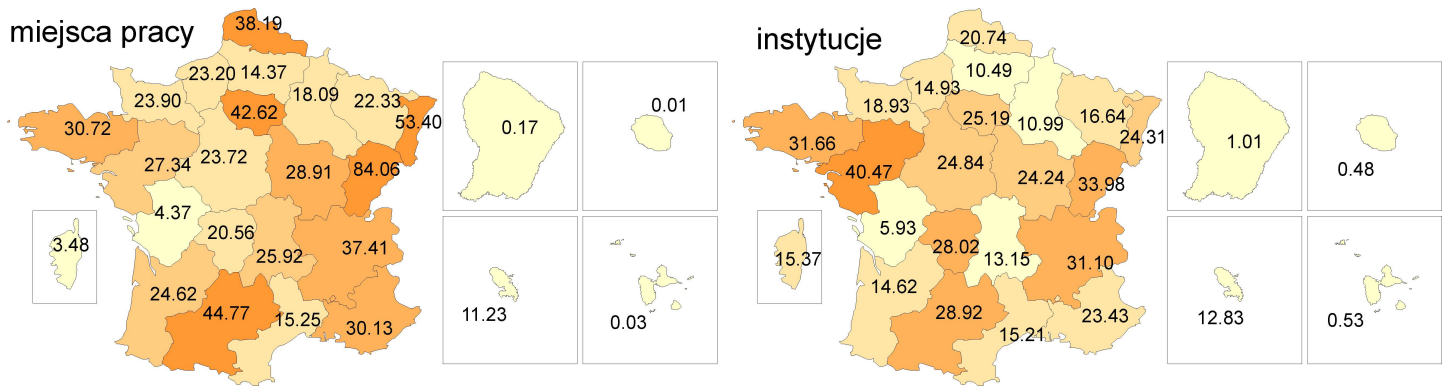

Udział miejsc pracy (na 1000 zatrudnionych) i instytucji $\square 14$ - $24 \square 28$ - 38 (na 10000 ogółu instytucji) w kastrach innowacyjnych w 2011 r. $\square<14 \quad \square 24-28 \square>38$

Ryc. 2. Udział miejsc pracy i instytucji w klastrach innowacyjnych w $2011 \mathrm{r}$.

Źródło: http://competitivite.gouv.fr

Mov’eo działa głównie w obszarach związanych z systemami transportowymi i technologiami samochodowymi, skupiając 70\% francuskich jednostek B+R z branży motoryzacyjnej (Mov'eo: Pôle de compétitivité > Moveo-Intelligence). Val d'Oise stanowi przykład udanej symbiozy sektora MŚP i wielkich korporacji transnarodowych: finansowych, przemysłowych i motoryzacyjnych. Każdy z owych podmiotów wytworzył sieć wysoko zróżnicowanej i rozbudowanej piramidy z lokalnymi podwykonawcami, nadając im sposobność udziału w globalnych rynkach zbytu. Tym samym znaczny fragment produkcji przemysłowej poddano przedsiębiorstwom regionalnym. Zgodnie z projektem EURO CAREX, łączącym usługi transportu kolejowego i lotniczego, zamierza się uczynić z Val d’Oise główne centrum logistyczne UE. O sukcesie technologiczno-innowacyjnym klastrów metropolitalnych przesądziła rozbudowana infrastruktura badawcza, wykwalifikowana kadra oraz kompatybilna współpraca na 
poziomie rządowo-regionalnym. W interesujący sposób o kwestii promowania działalności innowacyjnej w wymiarze regionalnym i ponadnarodowym wypowiedziała się K. Czech (2009) podkreślając, że proces ów prowadzi do kształtowania się tzw. „środowiska pobudzającego” sektor MŚP, czego potwierdzeniem jest zaprezentowany powyżej model francuski.

Realizacja polityki innowacyjnej stanowi silną przesłankę rozwojową warunkującą w departamentach i regionach Francji zamorskiej budowę gospodarki opartej na wiedzy (GOW). Działania zmierzające do wytworzenia stabilnego i konkurencyjnego sektora wysokich technologii w pierwszej kolejności obejmują prymarne obszary będące nośnikami GOW: edukację, naukę i aktywność badawczo-rozwojową, przemysł oraz usługi biznesowe i skierowane do społeczeństwa informacyjnego. Wskazane płaszczyzny wpisywały się w realizację Strategii Lizbońskiej - próbującej uczynić gospodarkę wspólnotową najbardziej konkurencyjną na świecie ${ }^{4}$, a obecnie nowego długookresowego programu rozwoju społeczno-gospodarczego UE, Europa 2020. Osiągnięcie założenia, zgodnie z którym 3\% wspólnotowego PKB zostanie przeznaczone na sektor badań i rozwoju, umożliwiłoby stworzenie do 2025 r. ok. 3,7 mln nowych miejsc pracy, z czego milion przeznaczonych dla naukowców (Polityka w zakresie badań naukowych i rozwoju technologicznego 2011). Pozostające jednocześnie regionami peryferyjnymi UE DROM, skutecznie dążą do budowy przewagi konkurencyjnej opartej na wiedzy i innowacjach, mając za przykład inne wysokorozwinięte regiony wspólnotowe, którym takowe działania zagwarantowały trwały rozwój.

Poprzez termin „,innowacja” rozumie się „wdrożenie w praktyce gospodarczej nowego produktu, usługi, procesu, metody marketingowej lub organizacyjnej" (Podręcznik Oslo: zasady gromadzenia i interpretacji danych dotyczących innowacji 2008, s. 48), lub jak podkreślają to inni, zastosowanie nowej wiedzy w procesie produkcji. W epoce globalizacji innowacje wpływają na konkurencyjność przedsiębiorstw i gospodarek oraz współdecydują o strukturze międzynarodowej współpracy (Gierańczyk 2009). Może być jednak innowacja procesem kreatywnej destrukcji, gdyż, jak słusznie zauważa J. Guinet (1995), jej uruchomienie zmienia dotychczasową strukturę rynku i gospodarki, prowadząc do zmian w systemach organizacyjnych i zarządzaniu. Działalność innowacyjna jest zbiorem wszystkich działań o charakterze naukowym, technicznym, organizacyjnym, finansowym i komercyjnym, powodujących implementację innowacji (Podręcznik Oslo: zasady gromadzenia i interpretacji danych dotyczących innowacji 2008).

W perspektywie finansowej 2014-2020 intensyfikacja procesów innowacyjnych w DROM w znacznym stopniu pozostanie uzależniona od wsparcia unijnego, w szczególności w ramach polityki spójności, wiążącej się m.in. z inwestowaniem w badania i działalność innowacyjną, szkolenia, OZE i wydajność energetyczną. Obserwowane w ostatnich latach rosnące znaczenie sektora $\mathrm{B}+\mathrm{R}$ w polityce wspólnotowej, wynikało z zysku gospodarczego wypracowanego przez lokaty z owego obszaru. Francuskie regiony zamorskie zaliczone zostały do grupy tzw. „regionów mniej rozwiniętych”, a zatem taki, gdzie wskaźnik PKB per

${ }^{4}$ Celów Strategii Lizbońskiej nigdy nie zrealizowano. Wydatki na sferę B+R nie osiągnęły nawet poziomu 2\% wspólnotowego PKB, zaś UE pozostała w tyle za Japonią i Stanami Zjednoczonymi. Głównym narzędziem pomiaru innowacyjności w Strategii był Summary Innovation Index (SII) - Sumaryczny Indeks Innowacyjności. Według niego Francję cechował m.in. wysoki wskaźnik innowacyjności sektora MŚP. Udział owych przedsiębiorstw kooperujących w zakresie innowacji w ogólnej ich liczbie wyniósł w 2006 r. 11,5\% (European Innovation Scoreboard 2007. Comparative analysis of innovation performance, s. 40). 
capita wynosi mniej niż 75\% średniego PKB UE. Nabędą tym samym prawo do ubiegania się o maksymalne współfinansowanie w ramach polityki spójności w przedziale 75-85\% (Polityka spójności na lata 2014-2020. Inwestycje w regiony europejskie 2011). Długookresową bazą wspólnotowej polityki innowacji pozostaje wspomniana Strategia Europa 2020 oraz towarzyszące jej inicjatywy i programy: Unia Innowacji, Europa efektywnie korzystająca z zasobów, Europejska agenda cyfrowa, Polityka przemysłowa w erze globalizacji, Program na rzecz nowych umiejętności i zatrudnienia, Młodzież w drodze oraz Europejski program walki z ubóstwem. Zwłaszcza pierwsza z wyszczególnionych inicjatyw, rozumiana jako klucz do ekorozwoju, wyraźnie współgra z aktywnymi staraniami DROM w budowie sustainable society - społeczeństwa zrównoważonego, mającego umiejętnie łączyć cele krótko i długookresowe oraz urzeczywistniać koncepcję regionów „uczących się”, będących magazynami wiedzy i pomysłów, a także wspomagających przepływ informacji (Florida 1995).

\section{REGIONALNE ZRÓŻNICOWANIE POZIOMU INNOWACYJNOŚCI WE FRANCJI}

Zważywszy, iż poziom progresu innowacyjnego państwa pozostaje uzależniony od współdziałania trzech czynników, do których A.H. Jasiński (2006) zaliczył: stopień rozwoju gospodarczego (przemysł), wiedzę (naukę) oraz politykę rządu (władzy regionalnej), kolejną część opracowania poświęcono analizie wyszczególnionych elementów, w kontekście wdrażania GOW w regionach Francji kontynentalnej i pozaeuropejskiej.

Według standaryzowanego parytetu siły nabywczej, departamenty zamorskie Francji pozostają w tyle za metropolią (ryc. 3A). Najlepszą sytuację odnotowano na Martynice, podczas gdy najgorsze wyniki posiadała Gujana Francuska. Biorąc pod uwagę średnioroczną zmianę wskaźnika PPS/os. w zróżnicowaniu regionalnym, najwyższą wartość we Francji posiadał departament Réunion (4,46\%), najniższą zaś francuska Gujana (1,29\%). Niekwestionowanymi liderami części metropolitalnej pozostawały regiony: Korsyka (3,95\%), Île-de-France (3,53\%) oraz Nord-Pas-de-Calais (3,15\%) (ryc. 4B).

Uwzględniwszy strukturę wybranych sektorów gospodarki według wartości dodanej należy odnotować, iż w obydwu częściach Francji systematycznie wzrasta znaczenie działalności profesjonalnej, a zatem naukowej i technicznej, co w przypadku części zamorskiej widoczne jest przede wszystkim w przypadku Martyniki (9,6\%) oraz Gwadelupy (8,1\%) (ryc. 4B). W układach regionalnych niekwestionowane pierwsze miejsce względem działalności profesjonalnej i rozbudowy sektora ITC zajmuje Île-de-France (ryc. 3B).

Istotną determinantą warunkującą rozwój procesów innowacyjnych jest wiedza. Przyjmując za kryterium liczbę naukowców na 1000 mieszkańców, wskaźnik ten dla DROM pozostaje na stosunkowo niskim poziomie $(2,30)$, zaś przeważająca ich większość pracuje dla sektora publicznego (ryc. 5A). Wyniki te wyraźnie kontrastują z sytuacją odnotowaną w części regionów metropolitalnych: Île-de-France, Rodan-Alpy, Prowansja-Alpy-Lazurowe Wybrzeże. Inną zauważalną różnicą jest fakt, iż w większości jednostek kontynentalnych miejscem zatrudnienia naukowców były placówki prywatne. Również w przypadku liczby patentów wartość dla DROM jest najmniejsza spośród regionów Francji (ryc. 5B; 6A). Jednakże analizując strukturę patentów zgłoszonych w DROM można zauważyć, że 
w porównaniu z Francją metropolitalną udział patentów innowacyjnych (ICT i biotechnologii) jest większy, szczególnie w przypadku Réunion i Gwadelupy (ryc. 6B).
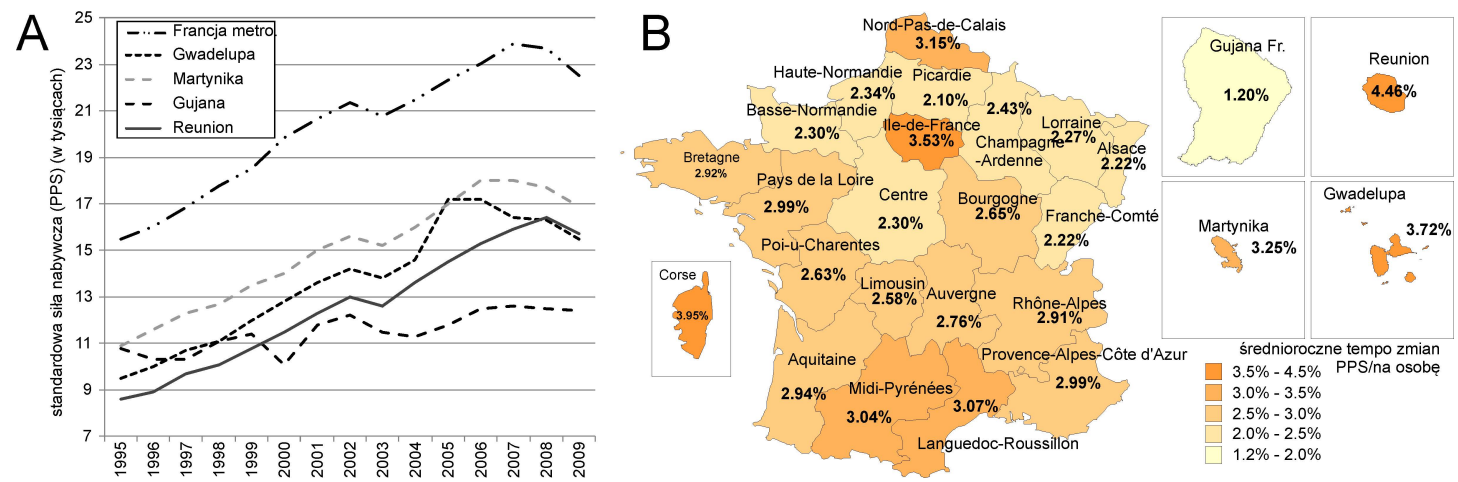

Ryc. 3. Zmiany wielkości PPS/os. (A) i średnioroczna zmiana wielkości PPS/os. (B) w regionach Francji kontynentalnej i departamentach zamorskich w latach 1995-2009

Źródło: opracowanie własne na podstawie danych EUROSTAT
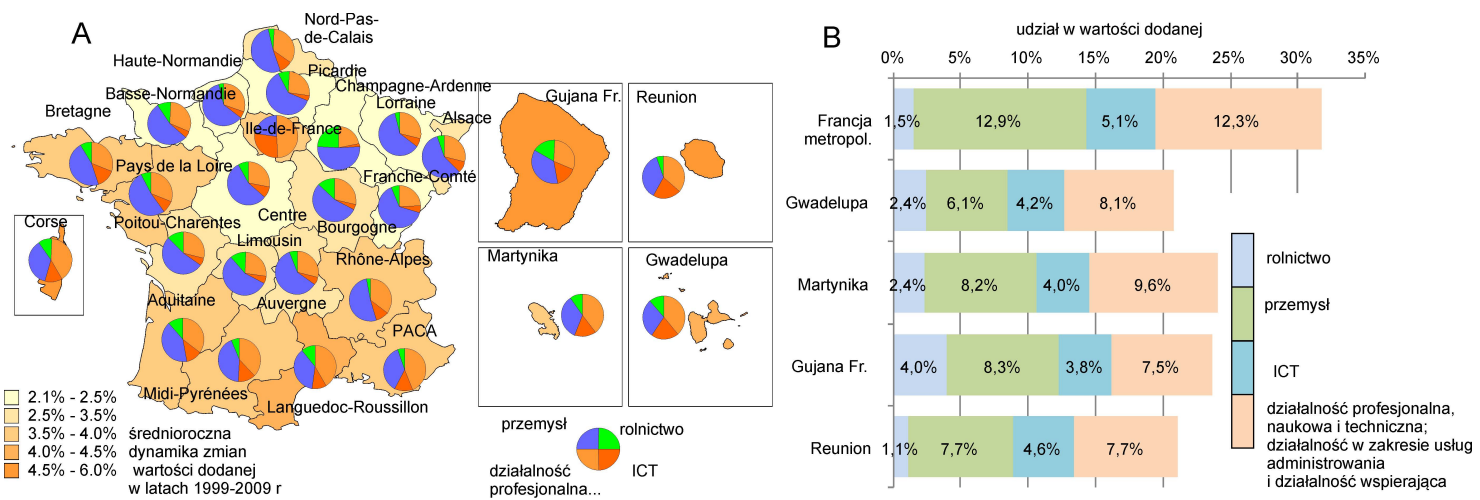

Ryc. 4. Struktura wybranych sektorów gospodarki w wartości dodanej oraz średnioroczna dynamika zmian wartości dodanej w latach 1999-2009 r. (A) i struktura wybranych sektorów gospodarki w wartości dodanej w 2009 r. (B)

Źródło: opracowanie własne na podstawie danych EUROSTAT
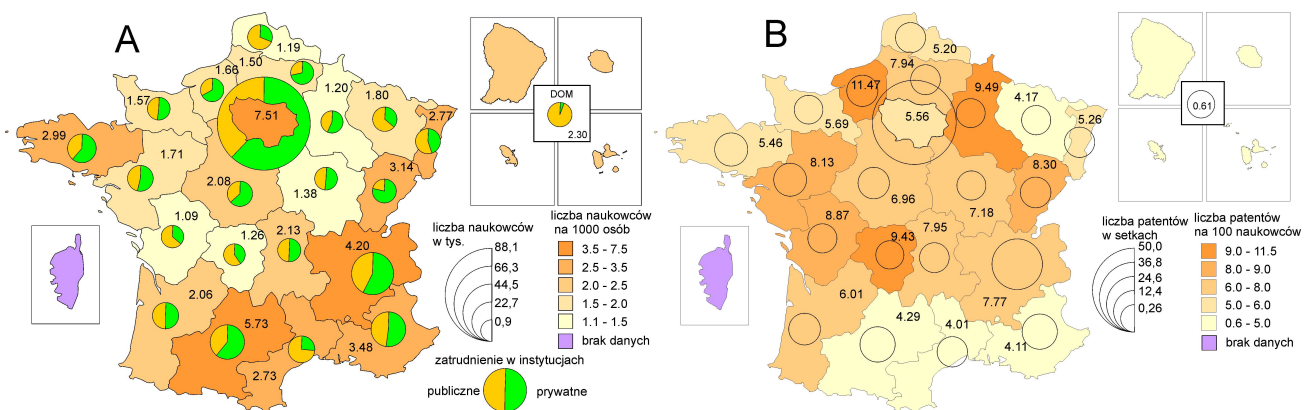

Ryc. 5. Liczba naukowców wg miejsca pracy (A) i liczba patentów (B) we Francji w 2010 r.

Źródło: opracowanie własne na podstawie danych INSEE i EUROSTAT 

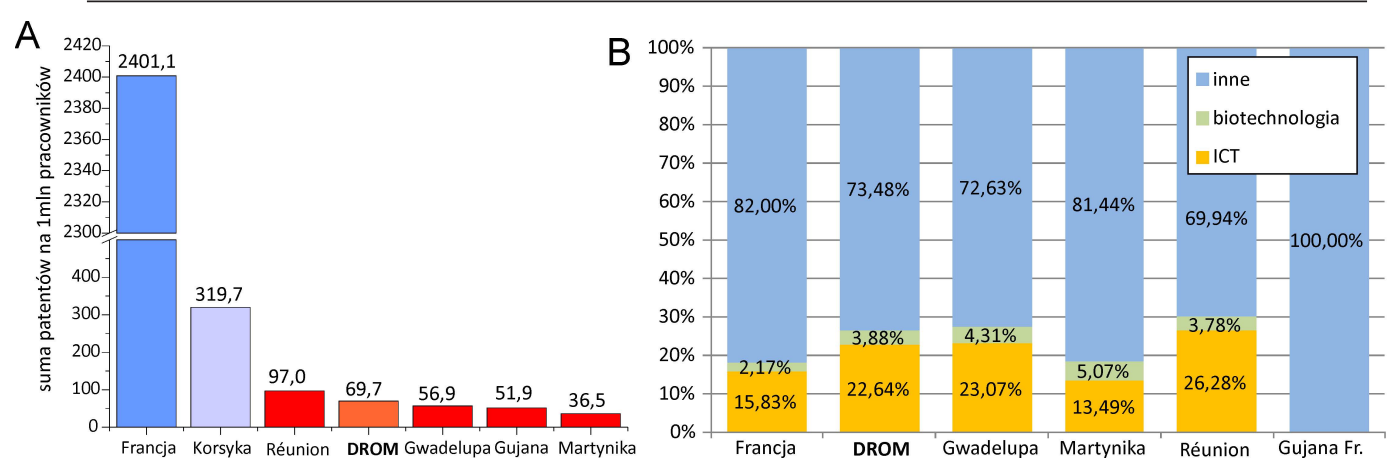

Ryc. 6. Liczba zgłoszeń patentowych na $1 \mathrm{mln}$ pracowników (A) oraz struktura zgłoszeń patentowych w latach 1999-2009 (B) w 2010 r.

Źródło: opracowanie własne na podstawie danych EUROSTAT

\section{AKTORZY INNOWACJI ZAMORSKICH}

Kolejną część opracowania poświęcono analizie reprezentacyjnych ośrodków innowacyjno-technologicznych Francji zamorskiej, zajmujących się prowadzeniem badań naukowych i prac rozwojowych oraz ich upowszechnianiem i wdrażaniem. W poniższej ekspozycji skupiono się na instytutach technicznych związanych z naukami ścisłymi i inżynierskimi oraz działającymi w obszarach: rolnictwo, ochrona środowiska, medycyna i biotechnologia oraz przemysł kosmiczny.

\section{PRAM - Martynika}

Centrum Badań Rolniczych i Przyrodniczych na Martynice (Pôle de Recherche Agroenvironnementale de la Martinique, PRAM) tworzą trzy instytucje publiczne: Narodowy instytut nauki i technologii dla środowiska i rolnictwa (Institut national de recherche en sciences et technologies pour l'environnement et l'agriculture, IRSTEA), Centrum Współpracy Międzynarodowej na rzecz Rozwoju Badań Agronomicznych (Centre de coopération internationale en recherche agronomique pour le développement, CIRAD) oraz Instytut Badań Naukowych dla Rozwoju (Institut de Recherche pour le Développement, IRD). Pomimo rosnącego znaczenia usług $\mathrm{w}$ gospodarce departamentalnej i systematycznego ograniczania supremacji rolnictwa, stanowi ono nadal kluczowy jej substrat. Znaczącym problemem Antyli francuskich w rozwoju rolnictwa nowoczesnego, obok czynników fizycznogeograficznych, są uwarunkowania pozaprzyrodnicze. Do pierwszej grupy należą przede wszystkim zmienność warunków klimatycznych i niebezpieczne zjawiska pogodowe: gwałtowne i ulewne deszcze, cyklony oraz powodzie (Leone 2002). Postępująca erozja gleb i niszczenie struktur nadbrzeżnych wzmagają deficyt ziemi uprawnej (Bosser, Levoy, Flageollet). 
Cel nadrzędny PRAM stanowi opracowanie systemu rolnictwa zrównoważonego, polegającego na racjonalnym wykorzystaniu w gospodarowaniu zasobów przyrodniczych, niwelując tym samym negatywny wpływ działalności rolniczej na środowisko. Działania te spowodować mają ograniczenie populacji agrofagów i zmniejszyć zachwaszczenie. Prowadzoną misję realizuje się w ramach pięciu podstawowych inicjatyw. Jednym z priorytetów jest rozwiązanie problemu zanieczyszczeń rolniczych, ze szczególnym uwzględnieniem kwestii dotyczących odkażania i biodegradacji. Niewłaściwe stosowanie środków ochrony roślin w przypadku Martyniki w latach 1973-1993 - chlorodekonu, doprowadziło do ciężkiego skażenia gleby. Obniżono tym samym jej urodzajność oraz zakłócono przebieg wegetacji roślin, głównie w północno-wschodniej części wyspy. Zajmujące powierzchnię $2500 \mathrm{~m}^{2}$ laboratoria i biura PRAM ulokowano w Petit Morne w gminie Le Lamentin. Wchodzące w skład centrum zespoły naukowe prowadzą badania nad sadownictwem, ogrodnictwem, nicieniami, pedologią, gospodarką przestrzenną oraz zagrożeniami dla środowiska. W przypadku departamentów karaibskich niebagatelnym wyzwaniem pozostaje zwalczanie prowadzącego do martwicy liści i przedwczesnego dojrzewania owoców grzyba cercosporiose noire oraz choroby Moko (Everard 2010). Badania gleby realizowane są w zamyśle poznania zachodzących w niej przemian, szczegółowych właściwości chemiczno-fizycznych oraz stopnia jej zanieczyszczenia. Kierunki badań w obszarze produkcji roślinnej dotyczą przede wszystkim doskonalenia technologii upraw grejpfrutów, owoców tropikalnych i cytrusowych. Działania badawcze z dziedziny geotechnologii nakierowano na wykorzystanie informacji mapowej w wizualizacji strefy przybrzeżnej - ICZM oraz zarządzanie środowiskiem.

Podejmujące inicjatywy z zakresu wykorzystania, przekształcania i ochrony zasobów przyrodniczych oraz agronomii PRAM, w rzeczywisty sposób wzmaga rozwój powyższych obszarów we Francuskich Indiach Zachodnich. Centrum, dysponujące nowoczesnym zapleczem badawczym, umożliwia prowadzenie badań interdyscyplinarnych, zaś poprzez silne związki z regionem wspomaga zaspokajanie jego potrzeb społeczno-gospodarczych.

\section{CRVOI - Réunion}

Przed powołanym w 2007 r. Centrum badań i monitoringu nowo pojawiających się chorób w regionie Oceanu Indyjskiego (Centre de recherche et de veille sur les maladies émergentes dans l'Océan Indien, CRVOI), postawiono cel gromadzenia danych wywiadowczych w zakresie chorób zakaźnych. Pośród założycieli CRVOI znalazły się metropolitalne instytucje naukowo-badawcze (CIRAD, CNRS, IP, IRD) ${ }^{5}$, Ministerstwo Szkolnictwa Wyższego i Badań Naukowych, Ministerstwo Zdrowia Młodzieży i Sportu, Rada Regionalna, Rada Generalna oraz Uniwersytet Réunion. Bezpośrednią genezę powołania ośrodka stanowiła zapoczątkowana w 2005 r. epidemia chikungunya, której obecność negatywnie wpłynęła

${ }^{5}$ Centrum Współpracy Międzynarodowej na Rzecz Rozwoju Badań Agronomicznych (Centre de coopération internationale en recherche agronomique pour le développement), Krajowe Centrum Badań Naukowych (Centre National de la Recherche Scientifique), Institut Pasteur, Instytut Badań Naukowych dla Rozwoju (Institut de Recherche pour le Développement). 
na departamentalną gospodarkę, przede wszystkim sektory przemysłu spożywczego, handlu oraz turystyki. Problem infekcji wirusowej, mającej w 2006 r. zasięg bezprecedensowy dotyczył ponad 1/3 populacji wyspy (Epidemia de Chikungunya en la Reunión: La expansion del IRD). Przeszło 15 tys. osób czynnych zawodowo pozostawało niezdolnych do pracy, sprzedaż detaliczna spadła o 20\%, zaś $60 \%$ firm budowlanych doświadczyło okresowych przerw w pracy (Payet, Hoarau 2005-2006). Zważywszy na słabość ekonomii Réunion w przypadku nieopanowania epidemii, zachodziło niebezpieczeństwo załamania gospodarczego.

Badania prowadzone w ramach CRVOI w pierwszej kolejności nakierowano na studiowanie czynników środowiskowych, ekologicznych i socjologicznych, dających możliwość lepszego poznania mechanizmów przesyłowych i zjawiska powstawania ognisk chorobotwórczych, schorzeń przenoszonych przez wektory oraz diagnozowanie parametrów monitorowania i ostrzegania. Pośród celów priorytetowych uwagę zwrócono na tworzenie nowych programów badawczych w zakresie patogenów, opracowanie innowacyjnych metod wczesnego przewidywania epidemii i zapobiegania jej rozprzestrzeniania się oraz ustanowienie współpracy z ośrodkami naukowymi UE i państwami trzecimi. W strukturze organizacyjnej CRVOI powołano m.in. zbierający się przynajmniej dwa razy w ciągu roku Komitet Sterujący oraz liczącą od 12 do 16 członków Radę Naukową, w której 50\% naukowców pochodzi z regionu Oceanu Indyjskiego, 25\% zaś z zagranicy (Convention constitutive du GIS « Centre de recherche et de veille sur les maladies émergentes dans l’Océan Indien 2006).

W opracowanym programie działań wyszczególniono cztery pozycje: identyfikacja chorób zakaźnych, nadzór nad szkoleniem magistrantów, doktorantów i młodych naukowców, promowanie kooperacji regionalnej oraz szersze zastosowanie ekstrakcji danych (data mining) w badaniu poszczególnych czynników. Pośród programów badawczych wspieranych przez CRVOI uwagę zwracała inicjatywa Exploration de la faune sauvage - Poznawanie przyrody, przyjmująca za cel zdiagnozowanie czynników zakaźnych w środowisku naturalnym południowo-zachodniej części Oceanu Indyjskiego oraz wskazanie gatunków mogących stanowić rezerwuar zarazków potencjalnych wektorów. W programie TIS Réunion podjęto zagadnienie ograniczenia liczebności przenoszących malarię komarów w biotypach wodnych i lądowych przy zminimalizowaniu stosowania preparatów chemicznych odznaczających się szkodliwością dla wielu innych pożytecznych gatunków owadów. Badanie ma wykazać, w jakim stopniu użycie biocydów pochodzenia naturalnego wpłynie na zniwelowanie populacji organizmów będących zagrożeniem dla populacji regionalnej. Program Animal Risk poświęcono analizie powstawania chorób zakaźnych u zwierząt gospodarskich i przenoszenia się ich na zwierzęta domowe. Poprzez działanie RUN-Emerge do 2014 r. zamierza się wypromować synergię pomiędzy regionalnymi podmiotami badawczymi, co usprawni walkę z chorobami zakaźnymi. Zaplanowano wzmocnienie naukowych platform technologicznych, organizację seminariów i konferencji międzynarodowych oraz upowszechnienie wyników badań opinii publicznej. Realizacja powyższych ścieżek może stanowić ważną determinantę w poprawie warunków życia oraz intensyfikacji gospodarczej departamentu i regionu. W ramach RUN-Emerge czyni się ponadto starania nakierowane na rozwój nauki stosowanej, a zatem kreowanie projektów o charakterze cywilizacyjnym, generujących popyt na innowacje. Wyzwalanie kreatywności pośród młodych naukowców wymaga większej 
ich partycypacji w stażach zagranicznych przy jednoczesnym tworzeniu międzynarodowych grup naukowych w Réunion. Urzeczywistniana jest tym samym koncepcja Europejskiej Przestrzeni Badawczej (EPB) ${ }^{6}$, której podstawowym zadaniem jest wypracowanie swobody w przepływie naukowców, wiedzy naukowej i technologii (Expected impacts - Runemerge - Université de la Réunion).

Zarządzane przez naukowe autorytety CRVOI należy do pionierskich ośrodków aranżujących programy badawcze, warunkujące społeczno-gospodarczy rozwój departamentu. Tym samym dołączyło Réunion do elity państw europejskich posiadających podobne jednostki o wysokim potencjale badawczym. CRVOI jest ponadto egzemplifikacją centrum naukowo-technologicznego mogącego skutecznie konkurować ze swymi wspólnotowymi odpowiednikami.

\section{CSG - Gujana Francuska}

Wyrazem intensyfikacji rozwoju technologicznego i innowacyjnego francuskiej Gujany pozostaje w pierwszej kolejności obecność Gujańskiego Centrum Kosmicznego (Centre Spatial Guyanais, CSG). Na pierwotną lokalizację ośrodka obrali Francuzi Algierię. Zważywszy jednak na postępujące procesy dekolonizacyjne i rozpad francuskiego imperium kolonialnego, a w konsekwencji przyznanie Algierii niepodległości w 1962 r., planu owego zaniechano (Dorocki 2005). Za budową centrum w Kourou przemawiała bliskość równika (ok. $500 \mathrm{~km}$ na północ), nadająca wystrzeliwanym rakietom dodatkową prędkość 460 m/s, a tym samym lepszą sposobność w umieszczaniu satelitów, zwłaszcza geostacjonarnych telekomunikacyjnych, na pożądanej orbicie przy mniejszym wykorzystaniu paliwa. Zwrócono również uwagę na niską gęstość zaludnienia, niewielkie prawdopodobieństwo występowania cyklonów i trzęsień ziemi oraz bliskość zbiornika wodnego (Satellite Programmes Overview - Launching Satellites). Jak zauważyli R. Aldrich i J. Connell (1992), Francuzi uczynili z CSG oś europejskiej polityki kosmicznej i podstawowy bastion regionalnej ekonomii. Mający znaczący udział w globalnej produkcji satelitów i wynoszeniu ich na orbitę, gujański przemysł kosmiczny stanowi przykład produktów wysokospecjalistycznych, odznaczających się znaczną konkurencyjnością w warunkach trwającego kryzysu gospodarczego.

Zapoczątkowana w połowie lat 60. inwestycja w znaczący sposób wpłynęła na wzrost gospodarczy departamentu (Guégan 1998). Rosnące zapotrzebowanie na siłę roboczą (tylko przy pierwszym etapie budowy partycypowało ok. 2500 osób), niwelowało wysokie bezrobocie w regionie. Otwarcie CSG w 1968 r. w pobliżu Kourou uczyniło z miasta jeden z największych i najważniejszych ośrodków zurbanizowanych regionu. Jeszcze w latach 70. Państwowy Ośrodek Badań Kosmicznych (Centre National d’Études Spatiales) przystąpił do

${ }^{6}$ Inicjatywa powołania EPB zrodziła się w czasie milenijnych obrad Szczytu Rady Europejskiej w Lizbonie, zaś rozbudowania doczekała się w Zielonej Księdze „Europejska Przestrzeń Badawcza: Nowe Perspektywy” z 2007 r. Zgodnie z konkluzją Rady Europejskiej z 4 lutego 2011 r. zobowiązano państwa członkowskie, aby do 2014 r. zakończyły proces tworzenia EPB. 
odsprzedawania lotów Europejskiej Agencji Kosmicznej ${ }^{7}$, następnie zaś międzynarodowej spółce astronomicznej Arianespace i innym firmom pozaeuropejskim. Wystrzeliwanie satelitów z kosmodromów należących do USA, Rosji, Chin i Japonii, zważywszy na ich geograficzną lokalizację, jest bardziej utrudnione. Prawidłowe funkcjonowanie CSG, wymagające obsługi wyrzutni rakietowych, satelitów, stacji kontroli lotów oraz fabryki paliwa, powoduje zapotrzebowanie na wykwalifikowanych specjalistów w zakresie technologii kosmicznej, przy właściwej ochronie zapewnianej przez oddziały Legii Cudzoziemskiej i żandarmerii narodowej. Gujańskie Centrum Kosmiczne stanowi bez wątpienia najnowocześniejszy i najważniejszy element departamentalnej gospodarki. Zgodnie z danymi z 2011 r. wygenerowało $15 \%$ regionalnego $\mathrm{PKB}$, dając na miejscu zatrudnienie ok. 1600 pracownikom i niemal 8 tys. w firmach powiązanych (Economie du spatial). Biorąc pod uwagę liczbę odwiedzających go turystów (26 034 w 2007 r.), należało do prymarnych atrakcji turystycznych francuskiej Gujany (Madeleine 2008). Infrastruktura naziemna, obejmująca wyrzutnie ELV, ELA-2, ELA-3, ELS - służącą dla rakiet Sojuz ST, należy do najnowocześniejszych w skali globalnej. Pierwotnie centrum obsługiwało również wyrzutnię CECLES (zdezaktywowaną w 1989 r.) przeznaczoną dla rakiet Europa 2 (Zak, Chabot). W wyniku zapoczątkowanej w 2004 r. przebudowy, dawną ELA-1 przekształcono w kompleks Zone de Lancement Vega (ZLV) Strefę startową rakiet Vega. W pierwszym starcie Vegi z 13 lutego 2012 r. partycypowały również polskie ośrodki naukowe: Politechnika Warszawska i Centrum Badań Kosmicznych $\mathrm{PAN}^{8}$.

Dążąca do roli pierwszorzędnego lidera w podboju wszechświata i głównego aktora areny międzynarodowej Europa, potrzebuje skutecznej polityki kosmicznej ${ }^{9}$. Rosnąca rola i wykorzystanie będących ważnym elementem codziennego życia systemów technologii kosmicznych, nadają w tym kontekście francuskiej Gujanie znaczenie szczególne. Dotyczy to w dużej mierze globalnego rynku nawigacji satelitarnej, w przypadku którego roczne tempo wzrostu sięga 25\%. Szacuje się, iż w 2020 r. wartość sektora może osiągnąć 275 mld euro, dając zatrudnienie ok. 100 tys. osób (EU White Paper: Space: A New European Frontier for an Expanding Union. An Action Plan for Implementing the European Space Policy 2003). Reasumując, działalność CSG stanowi główne narzędzie wspierania innowacji i rozwoju przemysłowego Gujany Francuskiej, samo zaś centrum należy do najnowocześniejszych i najbardziej zaawansowanych technologicznie tego typu ośrodków nie tylko w hemisferze zachodniej, ale i w skali globalnej w ogóle. Należy również zauważyć, iż opierająca się na zasadzie tzw. zwrotu geograficznego polityka przemysłowa ESA znacząco wzmaga intensyfikację jednostek naukowo-badawczych francuskiej części Gujany. Centrum jest przykła-

${ }^{7}$ European Space Agency (ESA) - organizacja międzynarodowa z siedzibą w Paryżu, utworzona w 1975 r., skupiająca 18 państw zachodnioeuropejskich, działająca na rzecz eksploracji i większego wykorzystania przestrzeni kosmicznej.

8 Należy odnotować, iż było to największe wydarzenie z udziałem Polski od lotu kosmicznego M. Hermaszewskiego w 1978 r. Po raz pierwszy także na orbitę wyniesiono rodzimego pikosatelitę PW-Sat o wymiarach 10x10x11 cm.

9 Traktat lizboński jako pierwszy stworzył podstawę prawną umożliwiającą UE prowadzenie polityki kosmicznej (art. 189 Traktatu o funkcjonowaniu Unii Europejskiej), potwierdzając jednocześnie współpracę z ESA na podstawie umowy ramowej, która weszła w życie w maju 2004 r. 
dem udanego sprzężenia wiedzy i inwestycji, co potwierdza założenie R. Żelaznego (2006: 14), zgodnie z którym ,pośrednie efekty przenikania z zasobem wiedzy kompensują bezpośrednie efekty kapitałowe”. Dzięki członkostwu w ESA, prowadząca od kilku dziesięcioleci działalność kosmiczną Francja uzyskała status międzynarodowego prekursora, podkreślając tym samym swój mocarstwowy charakter. Nie uczyniwszy z byłej kolonii swego integralnego fragmentu w 1946 r., osiągnięcie owej pozycji nie byłoby jednak możliwe, choćby z braku odpowiedniej lokalizacji geograficznej w części metropolitalnej. Tym samym Gujana Francuska nie tylko partycypuje w tworzeniu nowych technologii, lecz również jest miejscem ich wdrażania.

\section{IRD}

Instytut Badań Naukowych dla Rozwoju (Institut de Recherche pour le Développement, IRD), prowadzący działalność badawczą w ponad pięćdziesięciu państwach świata w zakresie m.in. medycyny, ekosystemów, ubóstwa i migracji, należy do najważniejszych francuskich instytucji naukowych. Poprzez system stypendialny, skierowany do krajów Południa (Bourses d'échanges scientifiques et technologiques, BEST), dąży się do wzmocnienia i konsolidacji potencjału badawczego naukowców, inżynierów i techników. Tematykę badań dla Antyli francuskich i krajów Ameryki Łacińskiej skoncentrowano wokół struktury i funkcjonowania biocenoz środowisk naturalnych, genomiki, zmian klimatycznych, wykorzystania zasobów odnawialnych i nieodnawialnych oraz społecznych i gospodarczych aspektów zrównoważonego rozwoju. Promując dialog naukowy i umacniając współpracę regionalną IRD opracował trzy inicjatywy: Młode zespoły AIRD (Jeunes équipes AIRD JEAI), Program doskonalenia kształcenia i badań naukowych na Południu (Programmes d'excellence pour l'enseignement et la recherche au Sud, PEERS) oraz Międzynarodowe Wspólne Laboratoria (Laboratoires mixtes internationaux, LMI). IRD partycypuje również w pracach gromadzącego dane o obszarach morskich i przybrzeżnych Mezoameryki obserwatorium Cousteau w Meksyku (Amérique Latine et Caraïbes - Institut de recherche pour le - IRD). Pośród innych przykładów współpracy międzynarodowej wskazać należy na le partenariat „Brésil-France”- partnerstwo „Brazylia-Francja”w dziedzinie hydrologii zapoczątkowane w 1982 r., kooperację z instytutem Bioclon (Meksyk) wyspecjalizowanym m.in. w produkcji surowic, z Centro Nacional de Prevención de Desastres (CENAPRED) - Krajowym Centrum ds. Zapobiegania Katastrofom w zakresie monitorowania aktywności wulkanicznej w Meksyku czy z peruwiańskim Instituto del Mar - Instytutem Morza. 
BUDOWANIE ZDOLNOŚCI INNOWACYJNYCH W REGIONACH

FRANCUSKICH INDII ZACHODNICH

Czyniąc starania w kierunku rozwoju innowacyjnego i technologicznego, departament Gwadelupy, przy wykorzystaniu wsparcia UE na lata 2007-2013, przystąpił do realizacji działań w czterech obszarach. Należały do nich odnawialne i alternatywne źródła energii, zwiększenie bioróżnorodności, upowszechnianie usług technologii komunikacyjnych i informacyjnych oraz prace z zakresu technologii materiałowych. Wybór owych materii wynikał w głównej mierze z upowszechniania w DROM idei développement durable - rozwoju zrównoważonego oraz specyfiki regionu zamorskiego.

Dążąc do ożywienia regionalnych osiągnięć naukowych wygenerowano kapitał na uruchomienie niewielkich zespołów badawczych i zakup nowoczesnej aparatury przy jednoczesnym gromadzeniu środków stypendialnych. Gwadelupa, jak również Martynika, przejawiały w ostatnich latach wyraźne aspiracje w ustanowieniu na ich obszarze międzynarodowych centrów badawczych, kierując swoją ofertę głównie do partnerów europejskich. Poza konferencjami i seminariami promowano również współpracę badawczą oraz program wymiany personelu naukowego. Zainicjowane działania skutkować miały niwelacją dysproporcji społeczno-gospodarczych między DROM karaibskimi a pozostałymi regionami wspólnotowymi, wskutek rozwijania potencjału pracowników naukowych i wypracowania trwałego partnerstwa badawczego. Poprzez realizację wytycznych Strategii Lizbońskiej nastąpiła intensyfikacja transferu technologicznego poprzez alienację wyników prowadzonych badań do firm, a tym samym wytworzenia sieci powiązań nauka - biznes. Za sensownością owej inicjatywy przemawiał fakt, iż w większości departamentalnych MŚP nie występowały odrębne jednostki badawczo-rozwojowe czy specjalnie wyodrębnione stanowiska. Prowadzona akcja informacyjna uświadomiła przedsiębiorstwom, że finansowanie innowacji nie musi dokonywać się tylko ze środków własnych i kredytów bankowych, lecz również z funduszy wspólnotowych i zagranicznych funduszy pomocowych. Pośród prowadzonych działań na szczególną uwagę zasługiwały: dzień regionalnych innowacji i transferu technologii, regionalne dni informacji o europejskich programach ramowych czy zainicjowanie działalności Regionalnego funduszu innowacyjności Gwadelupy (Le fonds régional pour l'innovation en Guadeloupe). Kierując się założeniem, iż rośnie znaczenie nauki i technologii w życiu codziennym, specjalny segment kampanii przygotowano z myślą o mieszkańcach departamentu. Wszystko po to, by wypracować krytyczny pogląd na temat rozwoju i zastosowań osiągnięć naukowych oraz rozbudzić zainteresowanie pośród młodych ludzi nie tylko badaniami, ale i nauką w ogóle. Przykładem takich inicjatyw są regionalne forum kariery naukowej oraz La Fête de la science - cykliczny festiwal Święto Nauki. Należy odnotować, iż z końcem ostatniej dekady, w porównaniu z pozostałymi DROM amerykańskimi, posiadała Gwadelupa największą liczbę zwycięzców w konkursach na tworzenie innowacyjnych firm technologicznych. Do najważniejszych departamentalnych ośrodków badawczych propagujących rozwój technologii i innowacji oraz stymulujących innowacyjność należały: Uniwersytet Antyli 
i Gujany Francuskiej oraz regionalne ośrodki badawcze ${ }^{10}$. Odpowiedzialność za tworzenie departamentalnych klastrów technologicznych, koordynowanie pracy regionalnych instytucji badawczych oraz upowszechnianie informacji w zakresie transferu technologii między podmiotami partnerstwa publiczno-prywatnego, powierzono Regionalnej Delegacji ds. Badań i Technologii (Délégation Régionale à la Recherche et à la Technologie en Guadeloupe, DRRTG). Gwadelupa, jak i pozostałe DROM, w zakresie prowadzonych badań naukowych realizuje wytyczne Międzyresortowego Komitetu Badań Naukowych i Technicznych (Comité interministériel de la recherche scientifique et technique, CIRST). Podobnie jak w regionach kontynentalnych, badania prowadzono w ramach Technologicznych Zespołów Badawczych (Les Équipes de Recherche Technologique, ERT), powoływanych na okres 3-5 lat oraz Krajowych Centrów Badań Technologicznych (Les Centres Nationaux de Recherche Technologique, CNRT), odpowiedzialnych za współpracę publicznych i prywatnych laboratoriów. Istotny czynnik wsparcia owych przedsięwzięć stanowiły środki finansowe w postaci funduszy zalążkowych oraz specjalnych kredytów podatkowych na badania (Crédit d'Impôt Recherche, CIR) o rozszerzonej procedurze stosowania po 1 stycznia 2008 r. W związku z tym, do podstawy CIR wlicza się $30 \%$ wydatków na $\mathrm{B}+\mathrm{R}$ poniesionych przez przedsiębiorstwo do kwoty $100 \mathrm{mln}$ euro i 5\% wydatków wykraczających poza ten próg (Politique du Ministère de la Recherche - Recherche-Guadeloupe).

Departament zamorski Gwadelupy pozostawał obszarem pilotażowym wdrażania Regionalnej Strategii Innowacji (Stratégie Régionale d'Innovation, SRI), dokumentu wskazującego, w jaki sposób władze regionalne będą działać na rzecz rozwoju, wspierając innowacje i innowacyjność. Zadaniem SRI było również zagwarantowanie, że owa progresja postępować będzie w sposób zharmonizowany i zrównoważony, poprzez ustanowienie współpracy i partnerstwa instytucji regionalnych, podmiotów gospodarczych, ośrodków naukowo-badawczych oraz organizacji samorządowych. Zważywszy, iż departamentalne MŚP należały do prymarnych kreatorów wzrostu innowacyjności, przyjęto w ramach SRI realizowanie działań na rzecz umacniania ich współpracy z jednostkami naukowymi. Zmierzać to miało do tworzenia klastrów, w ramach których działające tam firmy prowadziłyby współpracę, jak również konkurowały ze sobą. Jako udany przykład powyższej inicjatywy wskazać można Synergîle, w ramach którego badania i szkolenia realizowano głównie w zakresie OZE oraz materiałów znajdujących zastosowanie w budownictwie i przemyśle. W 2012 r. Synergîle skupiało sześćdziesięciu partnerów dzielących się wiedzą z zakresu tworzenia projektów innowacyjnych. W SRI dla Gwadelupy uwzględniono rozwiązania systemowe i organizacyjne promujące powiązania $\mathrm{B}+\mathrm{R} \mathrm{z}$ gospodarką, w tym konieczność

10 Międzynarodowe Centrum Badań i Pomocy Rozwojowej (Centre international de recherche et d'aide au développement, CIRAD), Biuro Badań Geologicznych i Górniczych (Bureau de recherche géologiques et minières, BRGM), Narodowy Instytut Badań Astronomicznych (Institut national de recherche agronomique, INRA), Narodowy Instytut Zdrowia i Badań Medycznych (Institut national en santé et recherche mdi cale, INSRM), Obserwatorium Sejsmologiczne i Wulkanologiczne Gwadelupy (Observatoire volcanologique et sismologique de Guadeloupe, OVSG-IPGP), Szpital Uniwersytecki (Centre hospitalier universitaire, CHU), Grupa Badań nad Informatyką i Matematyką Stosowaną (Groupe de Recherche en Informatique et Mathématiques Appliquées des Antilles-Guyane, GRIMAAG), Narodowy Instytut Badań Agronomicznych (Institut National de la Recherche Agronomique, INRA) oraz departamentalny oddział metropolitalnego Instytutu Pasteura (Institut Pasteur de Guadeloupe), (La recherche et l'innovation - Conseil Régional de Guadeloupe). 
wzrostu nakładów na pierwszy ze wskazanych elementów. Trzeba tu jednak podkreślić, iż realizacja szeregu wytycznych SRI pozostawała uzależniona od dynamiki rozwoju gospodarczego departamentu, w perspektywie minimum kilkunastoletniej. W celu wdrożenia SRI powołano komitet pilotażowy, obowiązkiem którego był nadzór nad procesem realizacji projektu, wydawanie raportów o roli poszczególnych grup roboczych oraz doradztwo metodologiczne i techniczne. Innym działaniem, rozpoczętym z końcem 2007 r., pozostawało przygotowanie przewodnika metodologicznego, zawierającego m.in. analizę sytuacji mikro i makroekonomicznej DROM. Dokonano również oceny gotowości do wdrażania innowacji przez przedsiębiorstwa regionalne. W przypadku Gwadelupy specjalnie opracowany w tym celu kwestionariusz nadesłano do 70 przedsiębiorstw. Na podstawie przeprowadzonych badań zdefiniowano oczekiwania i przeszkody w zakresie rozwoju innowacyjności. W poczet czynników hamujących wliczono przede wszystkim brak lub niedobór własnych środków finansowych, wysokie koszty wprowadzania innowacji, znaczny stopień ryzyka, niepewność w popycie na innowacyjne produkty, brak odpowiedniej infrastruktury technologicznej, niedobór odpowiednio wykwalifikowanego personelu oraz trudności w znalezieniu partnerów do współpracy. Przyjętą z końcem 2009 r. SRI dla Gwadelupy ujęto w czterech podstawowych operacjach: konsolidacja i rozwój wspólnej kultury innowacji, detekcja, promowanie i wspieranie koncepcji nowatorskich, wsparcie szkolnictwa wyższego oraz uczynienie innowacji regionalnych międzynarodowymi (L'Industrie en Guadeloupe. Un secteur face à ses défis 2010).

SRI przygotowana dla departamentu zamorskiego Martynika w pierwszej kolejności zwracała uwagę na zwiększanie konkurencyjności i atrakcyjności innowacyjnej regionu. Także w tym przypadku w opracowywaniu strategii uczestniczyli przedstawiciele różnych środowisk, w tym władz regionalnych ${ }^{11}$ i otoczenia przemysłowo-biznesowego. Powodzenie realizacji SRI warunkowano zatem współpracą państwa, regionu i społeczności lokalnej. W dokumencie zaproponowano trzy priorytetowe obszary wsparcia innowacji, zaś w pierwszej kolejności oparty na partnerstwie firm badawczych rozwój klastrów. Upatrywano w innowacjach remedium na izolację gospodarczą regionów peryferyjnych (Stratégie Régionale de l'Innovation - Technopole Martinique). W zamiarze zidentyfikowania obszarów sektora technologicznego wartych zainwestowania, przeprowadzono badanie mające określić realne perspektywy ich rozwoju. W pierwszej kolejności wskazano na technologie rolnicze, w tym nowe techniki w przetwórstwie trzciny cukrowej. Środowiskowe: energia z odpadów, recykling metali i tworzyw sztucznych, produkcja urządzeń fotowoltaicznych. Medyczne: dotyczące upowszechniania telemedycyny oraz nakierowane na zarządzanie zagrożeniami naturalnymi. Warto wskazać na kompatybilność między powyższymi sektorami a hasłami określonymi jako bieżące potrzeby społeczeństwa (agronomia, środowisko naturalne, medycyna, niebezpieczeństwa wynikające z działania sił przyrody), zaakcentowanymi we wrześniu 2004 r. w czasie sesji États Généraux de la Recherche en Martinique - Stanów Generalnych ds. Badań na Martynice. Szczególną uwagę w opracowanym dokumencie nakierowano na

${ }^{11}$ Rady Regionalnej, Regionalnej Delegacji ds. Badań i Środowiska (La Délégation Régionale à la Recherche et à la Technologie de Martinique, DRRT), Regionalnej Dyrekcji Przemysłu, Badań i Środowiska (Direction Régionale de l'Industrie, de la Recherche et de l'Environnement, DRIRE). 
konieczność kooperacji z innymi ośrodkami naukowymi, jak i partycypacji w zagranicznych projektach badawczych (Étude stratégique de développement des technologies sur le territoire communautaire. Projet technopolitain en Martinique pour le compte de la CACEM. Rapport final 2006). Jako potencjalne ośrodki współpracy wskazano na metropolitalne Montpellier Méditerranée Technopole oraz Europôle Méditerranéen de l'Arbois. Kwestie te powtórzono następnie w Białej Księdze Innowacji i jej dziesięciu propozycjach traktujących o rozwoju innowacyjnym (Livre Blanc 10 propositions pour favoriser l'innovation en France 2008) oraz w raporcie L’Innovation Vertuose (2010). Należy zauważyć, iż powyższe działania zainicjowane w $2006 \mathrm{r}$. w wielu aspektach nie wyszły poza sferę planowania, zaś pełna ich realizacja nastąpić może tylko w perspektywie średnio bądź długookresowej.

\section{WNIOSKI}

Polityka innowacyjna DROM doświadcza współcześnie zasadniczych przemian w perspektywie ekonomicznej i w analizie systemowej, obejmując swym zasięgiem znaczną liczbę rozproszonych aktorów. Gospodarka francuska, jak i światowa, w ogóle staje się coraz bardziej zależna od nagromadzonej w społeczeństwie wiedzy, wydajności systemu edukacyjnego, prowadzonych badań oraz praktycznego zastosowania nabytych kompetencji przez przedsiębiorstwa (Świtalski 2004). System innowacji zamorskich budowany jest wskutek wsparcia dwóch filarów, metropolitalnego i wspólnotowego. Znaczącą nowością we Francji pozaeuropejskiej pozostaje szybki rozwój innowacji szczebla regionalnego poprzez ustanawianie synergii naukowo-biznesowej. Dominujący w gospodarkach zamorskich sektor MŚP stanowi obszar w największym stopniu potrzebujący wsparcia w kreacji rozwiązań innowacyjnych. Uwagę zwraca również departamentalne zróżnicowanie tychże procesów, warunkowane odmiennymi potrzebami i zasobami. Ich peryferyjna lokalizacja należy do zasadniczych przeszkód wpływających na wymianę wiedzy oraz partycypacji w projektach realizowanych centralnie. Pośród najważniejszych czynników sprzyjających francuskiej innowacyjności wskazuje się zasoby ludzkie, otwartość systemów badań oraz ich finansowanie i wsparcie. Współczesne DROM przynależą do grupy najmniej innowacyjnych regionów Francji, co wynika głównie z zapóźnień w procesach dostosowawczych sektora naukowego oraz słabości własnych impulsów proinnowacyjnych, generowanych przez ośrodki metropolitalne. Należy jednak odnotować, iż Francja pozaeuropejska jest właścicielem centrów naukowych i innowacyjnych (działających w ramach Technopole Martinique, Technopole Réunion), w rzeczywisty sposób oddziaływujących na cały region. Przykładem może być ośrodek technologii kosmicznej (CSG), zajmujący wysoką lokatę w czołówce światowej, który osiągnął już masę krytyczną. Pomimo wykazanej w niniejszej pracy słabości zamorskiego potencjału naukowego (2,30 na 1000 mieszkańców), wysokich kosztów badań wdrożeniowych i postrzegania innowacji głównie przez pryzmat technologizacji, francuski klastering pozaeuropejski, w porównaniu z kontynentalnym, pozostający współcześnie inicjatywą w skali mikro, odznacza się sporym potencjałem rozwojowym. Dalszy jego progres warunkowany jest wsparciem metropolitalnym i wspólnotowym oraz ustanowieniem 
szerszej współpracy międzynarodowej. Poczynione na potrzeby niniejszego opracowania badanie udowodniło, że w pewnych obszarach (zgłoszenia patentowe z zakresu biotechnologii i ICT), wyprzedziły DROM swe odpowiedniki europejskie, co odzwierciedla ich potencjał, zaś departamenty karaibskie należą do liderów w zakresie działalności profesjonalnej: naukowej i technicznej. Niekwestionowane pierwsze miejsce pod względem przemysłu wysokiej techniki zajmuje od wielu lat region Île-de-France, należący także do grona dziesięciu najbardziej innowacyjnych regionów UE i będący zarazem jedyną francuską wyspą innowacji we Wspólnocie. Poszukujące sposobności podnoszenia swojej efektywności innowacyjnej DROM i ich wybrane odpowiedniki kontynentalne, stanowią przykład regionów „uczących się", z rozbudowanymi sieciami współpracy formalnej i nieformalnej oraz sieciami informacyjnymi - wzajemnie na siebie oddziaływującymi. Współcześnie zaś zdolność do uczenia się może przesądzać o sukcesie nie tylko jednostek, lecz także przedsiębiorstw, regionów i państw (Zarządzanie wiedzą w społeczeństwie uczącym się. Edukacja i umiejętności 2000). Trzeba również podkreślić, iż Francja traktuje innowacje jako priorytetowy czynnik swego rozwoju społeczno-gospodarczego, co ma jej zagwarantować w perspektywie długookresowej przewagę konkurencyjną w wymiarze wspólnotowym jak i ponadnarodowym.

\section{Literatura / References}

Aldrich, R., Connell, J. (1992). France's Overseas Frontier. Départements et Territoires D'Outre-Mer. New York: Cambridge University Press.

Almandin, D., Chabbi, S. (2007). La problématique de la chlordécone à la Martinique. Paris: Université Paris-Sud. Pozyskano z: http://www.cyclistesdumonde.org/userfiles/file/ Problematique_de_la chlordecone_a_la_Martinique.pdf.

Amérique Latine et Caraïbes - Institut de recherche pour le - IRD. (2012, 9 grudnia). Pozyskano z: http://www.ird.fr.

Borowiec, M., Dorocki, S. (2011). Rola kapitału ludzkiego w procesie kształtowania innowacyjności układów regionalnych Francji. Rozprawy Naukowe Instytutu Geografii i Rozwoju Regionalnego Uniwersytetu Wroctawskiego, 19, 215-230.

Borowiec, M., Dorocki, S., Jenner, B. (2009). Wpływ zasobów kapitału ludzkiego na kształtowanie społeczeństwa informacyjnego i innowacyjności struktur przemysłowych. Prace Komisji Geografii Przemystu Polskiego Towarzystwa Geograficznego, 13, 95-109.

Ciok, S., Dobrowolska-Kaniewska, H. (2009). Polityka innowacyjna państwa a regionalny potencjał innowacyjny. Przykład Dolnego Śląska. Rozprawy Naukowe Instytutu Geografii i Rozwoju Regionalnego Uniwersytetu Wrocławskiego, 7.

Claeys, A., Gorges, J.P., Habib, D., Lasbordes, P., Tron, G. (2009). Mission d'évaluation et de contrôle (MEC) sur les perspectives des pôles de compétitivité. Rapport d'information. Paris: Assemblée Nationale.

Convention constitutive du GIS «Centre de recherche et de veille sur les maladies émergentes dans l'Océan Indien (2006). Pozyskano z: http://www.crvoi.org/IMG/pdf/.

Convention_constitutive_du_GIS_CRVOI.pdf.

Czech, K. (2009). Infrastruktura instytucjonalna w procesie wspierania działalności innowacyjnej MŚP we Francji - wnioski dla Polski. W: D. Kopycińska (red.), Ekonomiczne problemy funkcjono- 
wania wspótczesnego świata. Szczecin: Katedra Mikroekonomii Uniwersytetu Szczecińskiego, $142-153$.

Dorocki, S. (2005). Historia francuskich podziałów administracyjnych Algierii. Studia Historyczne, $48,75-90$.

Dorocki, S. (2008). Gospodarka oparta na wiedzy w założeniach Strategii Lizbońskiej na przykładzie Francji. Przedsiębiorczość - Edukacja, 4, 183-191.

Dorocki, S., Brzegowy, P. (2012). Regionalne zróżnicowanie kształcenia we Francji w aspekcie rozwoju przedsiębiorczości departamentów zamorskich. Przedsiębiorczość - Edukacja, 8, 229-258.

Dorocki, S., Jenner, B. (2009). Wpływ wielkości nakładów inwestycyjnych w sektorze B+R na regionalne zróżnicowanie tempa rozwoju Francji. Przedsiębiorczość - Edukacja, 5, 188-197.

Economie du spatial. (2012, 9 grudnia). Pozyskano z: http://www.cnes-csg.fr/web/CNES-CSGfr/9759-economie-du-spatial.php.

Epidemia de Chikungunya en la Reunión: La expansion del - IRD. (2012, 9 grudnia). Pozyskano z: http://es.ird.fr.

Étude stratégique de développement des technologies sur le territoire communautaire. Projet technopolitain en Martinique pour le compte de la CACEM. (2006). Pozyskano z: http://technopolemartinique.net/IMG/pdf/Etude_ADIT_2005_Technopole_Martinique-2.pdf.

Space: A New European Frontier for an Expanding Union. An Action Plan for Implementing the European Space Policy. (2003). EU White Paper. Pozyskano z: http://eur-lex.europa.eu/LexUri Serv/site/en/com/2003/com2003_0673en01.pdf.

European Innovation Scoreboard 2007. (2008). Comparative analysis of innovation performance, Pro Inno Europe Paper. Pozyskano z: http://www.earto.eu/uploads/media/ European_Innovation Scoreboard_2007.pdf.

Everard, C. (2010). La cercosporiose noire fait trembler les bananiers, France-Antilles Martinique. Pozyskano z: http://www.martinique.franceantilles.fr.

Expected impacts - Runemerge - Université de la Réunion. (2012, 9 grudnia). Pozyskano z: http:// runemerge.univ-reunion.fr.

Florida, R. (1995). Toward the learning region. Futures, 27(5), 527-536.

Gierańczyk, W. (2009). Innowacyjność jako główny filar społeczeństwa informacyjnego Europy. Prace Komisji Geografii Przemystu Polskiego Towarzystwa Geograficznego, 13, 82-94.

Godowska, M. (2012). Region uczący się - uwarunkowania i determinanty rozwoju na przykładzie województwa małopolskiego. Przedsiębiorczość - Edukacja, 8, 278-286.

Guégan, F. (1998). L'Atlantique et la Compagnie Nantaise et Morbihannaise de Navigation. Norois, 180.

Guinet, J. (1995). National Systems of Financing Innovation. Paris: OECD.

Hingel, A.J. (1995). Co-development across the EC's External Borders. W: A. Kukliński (red.), Baltic Europe in the Perspective of Global Change. Warszawa: Oficyna Naukowa Euroreg, 21-33.

Jasiński, A.H. (2006). Innowacje i transfer techniki w procesie transformacji. Warszawa: Centrum Doradztwa i informacji Difin.

L'Industrie en Guadeloupe. Un secteur face à ses défis (2010). Antilles-Guyane: INSEE, DRIRE. Pozyskano z: http:/www.insee.fr/fr/insee_regions/guadeloupe/themes/ etudes_detaillees/drire/ drire.pdf.

L'Innovation Vertuose. (2010). RETIS. Pozyskano z: http://technopolemartinique.net/IMG/pdf/ innovation_vertuose.pdf. 
Livre Blanc 10 propositions pour favoriser l'innovation en France. (2008). RETIS. Pozyskano z: http:// technopolemartinique.net/IMG/pdf/livre_blanc.pdf.

Madeleine, É. (2008). Des efforts sur l'offre produit Guyane. Antiane, 70. Pozyskano z: http://www. insee.fr/fr/insee_regions/guyane/themes/ae_bilan/aes70gy/aes70gy_art12.pdf.

Markowski, T. (1999). Zarzadzanie rozwojem miast. Warszawa: Wydawnictwo Naukowe PWN.

Mov'eo: Pôle de compétitivité > Moveo-Intelligence Economique. (2012, 9 grudnia). Pozyskano z: http://www.pole-moveo.org/moveo-intelligence-economique.php.

Payet, A.M., Hoarau, G. (2005). Épidémie de chikungunya à la Réunion. Rapport d'information, 236. Pozyskano z: http://www.senat.fr/rap/r05-236/r05-2361.pdf.

Podręcznik Oslo: zasady gromadzenia i interpretacji danych dotyczacych innowacji. (2008). OECD, EUROSTAT. Warszawa: Ministerstwo Nauki i Szkolnictwa Wyższego, Departament Strategii i Rozwoju Nauki.

Pôle de recherche agro-environnementale de la Martinique (PRAM). (2012, 9 grudnia). Pozyskano z: http://www.pram-martinique.org.

Politique du Ministère de la Recherche - Recherche-Guadeloupe. (2012, 9 grudnia). Pozyskano z: http://www.recherche-guadeloupe.org.

Polityka spójności na lata 2014-2020. Inwestycje w regiony europejskie. (2011). Panorama Inforegio, 40, Bruksela: Urząd Publikacji KE.

Polityka w zakresie badań naukowych i rozwoju technologicznego. (2012, 9 grudnia). Pozyskano z: http://www.europarl.europa.eu/ftu/pdf/pl/FTU_4.14.pdf.

Porter, M.E. (1998). Clusters and the new economics of competition. Boston: Harvard Business Review.

Satellite Programmes Overview - Launching Satellites. (2012, 9 grudnia). Pozyskano z: http://www. eumetsat.int.

Stratégie Régionale de l'Innovation - Technopole Martinique. (2012, 9 grudnia). Pozyskano z: http:// www.technopolemartinique.org/Strategie-Regionale-de-1.html.

Świdurska, A. (2009). Kształtowanie się przemysłu wysokiej techniki w Polsce. Prace Komisji Geografii Przemystu Polskiego Towarzystwa Geograficznego, 13, 56-67.

Świtalski, W. (2004). Ekonomia a postęp techniczny: Rola nauki w innowacyjności gospodarek. W: E. Okoń-Horodyńska (red.), Rola polskiej nauki we wzroście innowacyjności gospodarki. Warszawa: PTE, 73-110.

Synergîle Guadeloupe - Capenergies. (2012, 9 grudnia). Pozyskano z: http://www.capenergies.fr/index.php?Capenergies-guadeloupe.

Wierżyński, W. (2011). Region, który klastrami stoi. Pozyskano z: http://www.pi.gov.pl/parp.html.

Zak, A., Chabot, A. (2012, 9 grudnia). The ELEA-2 launch complex in Kourou. French Guiana. Pozyskano z: http://www.russianspaceweb.com/kourou_ela2.html.

Zarzadzanie wiedza $w$ społeczeństwie uczacym się. Edukacja i umiejętności. (2000) OECD, Ministerstwo Gospodarki, Departament Strategii Gospodarczej.

Żelazny, R. (2006). Wiedza jako determinanta rozwoju gospodarczego - problemy i kontrowersje w aspekcie koncepcji gospodarki opartej na wiedzy. W: D. Kopycińska (red.), Kapitał ludzki w gospodarce opartej na wiedzy. Szczecin: Printgroup, 7-17.

Zioło, Z. (2008). Procesy transformacji przemysłowych układów przestrzennych na tle zmieniającego się otoczenia. Prace Komisji Geografii Przemystu Polskiego Towarzystwa Geograficznego, 10, $11-22$.

Zioło, Z. (2009). Rola przemysłu w procesie kształtowania społeczeństwa informacyjnego. Prace Komisji Geografii Przemystu Polskiego Towarzystwa Geograficznego, 13, 11-20. 
Sławomir Dorocki, dr, Uniwersytet Pedagogiczny w Krakowie, Instytut Geografii, Zakład Przedsiębiorczości i Gospodarki Przestrzennej w Krakowie, doktor nauk humanistycznych w dyscyplinie historia (Instytut Europeistyki - Uniwersytet Jagielloński). Adiunkt w Instytucie Geografii Uniwersytetu Pedagogicznego w Krakowie. Jego zainteresowania badawcze skupiają się wokół problematyki regionów i procesów regionalizacji społeczno-gospodarczej, ze szczególnym uwzględnieniem zróżnicowania przestrzeni europejskiej oraz procesów integracji europejskiej i uwarunkowań historycznych.

Sławomir Dorocki, Ph.D., Pedagogical University of Cracow, Institute of Geography, Department of Entrepreneurship and spatial Management.

Graduated from Pedagogical University in Cracow MA degree in geography, Ph.D. in history (Institute of European Studies of the Jagiellonian University). Adiunkt (assoc. professor) at Pedagogical University of Cracow, Institute of Geography. His research interests are tied with regional problems and processes of socio-economic regionalization, with particular emphasis on the diversity of Europe, processes of European integration and historical conditions.

Paweł Brzegowy, mgr, Uniwersytet Pedagogiczny w Krakowie, Instytut Geografii, Zakład Przedsiębiorczości i Gospodarki Przestrzennej.

Absolwent Instytutu Nauk Politycznych i Stosunków Międzynarodowych Uniwersytetu Jagiellońskiego, doktorant w Instytucie Geografii Uniwersytetu Pedagogicznego im. KEN w Krakowie. Jego główne zainteresowania badawcze dotyczą historii społeczno-gospodarczej departamentów i wspólnot Francji pozaeuropejskiej oraz francuskiej i polskiej szkoły geografii politycznej.

Pawel Brzegowy, graduate of the Institute of Political Studies and International Relations at the Jagiellonian University, doctoral student at the Faculty of Geography at the Pedagogical University of Cracow named after the National Education Commission. His main research interests focus on social and economic history of extra-European France departments and communities as well as French and Polish school of political geography.

adres/address: Uniwersytet Pedagogiczny w Krakowie

Instytut Geografii, Zakład Przedsiębiorczości i Gospodarki Przestrzennej

ul. Podchorążych 2, 30-084 Kraków, Polska

e-mail: sdorocki@up.krakow.pl

pawel.brzegowy@uj.edu.pl 